\title{
Effect of Variations Concentration and pH of Liquid Smoke in the Immersion With Various Types of Fish
}

\author{
Farida Ali ${ }^{1, *}$ Lia Cundari $^{1}$ Siti Miskah ${ }^{1}$ Hendri Prasetyo ${ }^{2}$ \\ ${ }^{1}$ Lecturer, Faculty of Chemical Engineering, Universitas Sriwijaya \\ ${ }^{2}$ Student, Faculty of Chemical Engineering, Universitas Sriwijaya \\ *Corresponding author. Email: umikrachmi@gmail.com
}

\begin{abstract}
Rubber seeds contain cellulose and lignin, therefore rubber seed could be used as raw material for liquid smoke. Liquid smoke contains lactic acid and phenol which have antibacterial properties. The purpose of this study is to test the antibacterial activity of liquid smoke shells and rubber seeds on the number of bacterial colonies in Mackarel fish (Euthynus affinis)(furthermore cited as mackerel). Mackarel fish is a sea fish that has $69.40 \%$ moisture content, 100 kcal energy, 13.7 protein, $1.5 \mathrm{~g}$ fat, $8 \mathrm{~g}$ carbohydrate, $92 \mathrm{mg}$ calcium, $606 \mathrm{mg}$ phosphorus, and $1.7 \mathrm{mg}$ iron. Variations made in this study in the form of raw materials, the concentration of dilution of liquid smoke, and soaking time of the fish in liquid smoke. The raw materials used are rubber seed shells, rubber seeds, and a mixture of both. Concentrations used to dilute liquid smoke are 3\%,6\%,9\%,12\%, and 15\%. While the fish soaking time is 30 minutes, 60 minutes, and 90 minutes. Identification of qualitative chemical compounds using the GC-MS method, while identification of the number of bacterial colonies using the total plate number (ALT) method. The results of this study are the rubber seed shell is the best raw material in the manufacture of liquid smoke. The $9 \%$ concentration can reduce the number of colonies, but better results will be obtained at concentrations of $12 \%$ and $15 \%$. Then, the best soaking time is 90 minutes, but at the time of immersion 60 minutes can reduce the number of bacterial colonies. Thus, the best results obtained were rubber seed shell raw material with a concentration of $15 \%$ and a soaking time of 60 minutes, with a bacterial colony of 2.12 x $102 \mathrm{CFU} /$ gram of fish.
\end{abstract}

Keywords: antibacterial, liquid smoke, rubber seeds

\section{INTRODUCTION}

Indonesia is one of the largest rubber producing countries in the world along with Thailand and Malaysia. Rubber is one of Indonesia's main non-oil and gas export commodities. National rubber production in 2018 reached 3.63 million tons, which continues to increase from the previous year. According to the Central Statistics Agency, exports of crumb rubber (2018) reached 2.74 million tons.

One form of increasing the sale value of an ingredient is by changing the composition of the material into a high-selling product. Various studies mention that rubber seeds have potential as a raw material in the pyrolysis process because rubber seeds contain components of hemicellulose, cellulose, and lignin, which are then used as preservatives. This is because liquid smoke consists of phenol compounds, carbonyl, and organic acids that can inhibit the growth of bacteria in food. (Fadillah, dkk. 2015) [2].

At first, rubber seeds were known as less useful material. However, several studies have obtained the results of one of the benefits of rubber seeds as a food preservative through the pyrolysis process. Rubber seeds (which are divided into shells and the contents of rubber seeds) contain a lot of lignin, cellulose, and acids that can be decomposed into phenol compounds and mixtures of organic acids through the process of pyrolysis. The process of pyrolysis of the shells and rubber seeds will produce liquid smoke as a result of condensation with air conditioning media. Liquid smoke can be applied to various types of food ingredients in various ways, such as spraying, dyeing, or mixed directly.

The application of liquid smoke as a preservative can be applied to raw materials, such as fish. Various types of fish, such as the types of mackerel that decline 
in quality within a certain time if the fish are stored at room temperature or left in the open,.mackerel can only be stored for up to 24 hours at room temperature which is analyzed based on total bacteria, taste, texture, odor, and various other analyzes. This will certainly harm many parties, such as, mackerel which is easily rotten due to long transportation, mackerel fish belonging to traders who do not sell quickly in the morning.

Based on the considerations that have been described before, a study was conduct-ed about the potential of rubber seeds as a preservative for fish through the pyrolysis process. This is intended to prevent the decline in fresh fish so that it can last longer.

\section{LITERATURE REVIEW}

\subsection{Rubber Plants}

The rubber plant is a tree that grows tall and has a trunk with a size large enough. Adult rubber tree height can reach 15-25 m. Plant stems grow straight and have a high branching, but some rubber trees are slightly tilted. Strong winds can release broken or fallen stems.

The stems of rubber plants contain sap known as latex. Rubber plants need sunlight with a high enough intensity, which is between 5-7 hours every day. Green rubber leaves, which will turn yellow or red when falling. The rubber leaf consists of the main leaf stalk and sapling. The length of the main leaf stalk is $3-20 \mathrm{~cm}$ and the growth media of rubber plants is the type of soil that is per the conditions for growing rubber plants, namely young volcanic soil, old volcanic soil, or peat soil. (Setyawardhani dkk, 2010)[4].

\section{2. $\quad$ Rubber Seed}

Productive rubber plants can produce 0.8-1.2 tons/hectare in 1 year. Rubber seeds or (Hevea Brasiliense) in Indonesia are still a by-product that can be categorized as not being utilized optimally, because only a small portion is used as seeds. (Eka dkk, 2010)[5] Rubber seeds have a proportion of parts that can be consumed around $57 \%$.

The nutritional content contained in rubber seeds has been studied by several previous researchers who showed the results of the rubber seed proximate test conducted by Eka et al. (2010)[6]. Besides, rubber seeds contain high levels of cyanide acid (HCN) so that it can endanger human health. Therefore, it is necessary to carry out a process of reducing $\mathrm{HCN}$ on rubber seeds before it is processed into food raw materials.

Rubber seeds in various regions have not been used maximally as a useful product. However, several studies have mentioned that rubber seeds can function as an alternative food ingredient, for example as a basis for making tempeh. While the rest, rubber seeds are only allowed to fall to the ground and are not used directly by the community as a material that has a sale value.

Table 1 Proximate rubber test results

\begin{tabular}{cc}
\hline Nutrient Content & Content $(\mathbf{g} / \mathbf{1 0 0 g})$ \\
\hline Protein & $17,41 \pm 0,01$ \\
Carbohydrate & $6,99 \pm 0,01$ \\
Ash & $3,08 \pm 0,01$ \\
Fat & $68,53 \pm 0,04$ \\
\hline
\end{tabular}

Table 2 Chemical components contained in rubber fruit shells

\begin{tabular}{cc}
\hline Constituent Components & Percentage \\
\hline Cellulose & 48,64 \\
Lignin & 33,54 \\
Pentosan & 16,81 \\
Ash Content & 1,25 \\
Silica Content & 0,52 \\
\hline
\end{tabular}

\subsubsection{Pyrolysis}

Pyrolysis is the process of decomposition or breakdown of raw materials which produce a product in the form of liquid smoke, which occurs in the presence of combustion heat and limited oxygen so that from the process gas, liquid and charcoal are obtained which are affected by the type of material, method, and operating conditions. Pyrolysis can be interpreted as incomplete combustion because it causes complex carbon compounds not to be oxidized to carbon dioxide in raw materials that contain cellulose, hemicellulose, and lignin compounds (Girrard, 1992 in Atmaja, 2009)[9].

The pyrolysis process involves various reactions in the form of decomposition, oxidation, polymerization, and condensation reactions. The reactions that occur during wood pyrolysis are removal of water from wood at $120-150^{\circ} \mathrm{C}$, pyrolysis of hemicellulose at $200-250^{\circ} \mathrm{C}$, pyrolysis of cellulose at $280-320^{\circ} \mathrm{C}$, and pyrolysis of lignin at $400^{\circ} \mathrm{C}$. Pyrolysis at $400^{\circ} \mathrm{C}$ produces compounds that have high organoleptic quality and at even higher temperatures condensation reactions will occur and formation of new compounds and oxidation of condensation products are followed by linear increases in tar compounds and aromatic polycyclic hydrocarbon compounds. (Girrard, 1992 in Atmaja, 2009)[11] 
According to Purwaningtyas (2010)[12], the decomposition event in the pyrolysis process can be divided into five zones. Zone I at a temperature of less than $100 \mathrm{oC}$, the evolution of water content generally occurs, zone II at a temperature of $200-250 \mathrm{oC}$ raw material begins to decompose, zone III at a temperature of $250-350 \mathrm{oC}$ predominantly hemicellulose decomposition, zone IV at $350-500 \mathrm{oC}$ occurs cellulose and lignin decomposition, and zone $\mathrm{V}$ at temperatures above $500 \mathrm{oC}$ lignin decomposition.

Pyrolysis process results in three types of product classifications namely gas, distillate, and residue. The gases released are mostly $\mathrm{CO} 2$ and some flammable gases such as $\mathrm{CO}, \mathrm{CH} 4$, or $\mathrm{H} 2$ and other low-level hydrocarbons. The resulting distillate is liquid smoke and tar. The main composition of the products stored is methanol and acetic acid. The other part is a minor component, namely phenol, methyl acetate, formic acid, butyric acid, and others. Residues (carbon), cellulose, hemicellulose, and lignin content have different amounts based on the raw material used. However, wood generally contains two parts cellulose, one part hemicellulose, and one part lignin.

\subsection{Liquid Smoke}

Liquid smoke is obtained from burning materials that contain lots of cellulose, hemicellulose, and lignin which contain phenols, acid compounds, and their derivatives. Raw materials that can be used to produce liquid smoke include shells, coconut fibers, organic waste, coffee shells, bamboo, rice straw, or various other raw materials (Sutin, 2008)[16]. The nature of liquid smoke is influenced by the main components namely cellulose, hemicellulose, and lignin which have proportions that vary depending on the type of material to be hydrolyzed.

Liquid smoke can be used as a latex coagulant with the functional properties of liquid smoke such as antifungal, antibacterial, and antioxidants so that it can improve the quality of the rubber product produced. When compared to agglomerating with formic acid, the use of liquid smoke is superior, because the lumpy rubber sap does not smell. The addition of formic acid triggers the growth of bacteria so that ammonia and sulfide appear. It is this compound that causes the gum to coagulate and stink.

\section{4. $\quad$ Liquid Smoke Components}

Liquid smoke is obtained by burning hardwood and softwood which contain a lot of components of cellulose, hemicellulose, and lignin. More than 300 compounds can be isolated from the pyrolysis process smoke from a total of more than 1000 . The compounds that have been detected in the smoke can be grouped into several groups such as phenols, carbonyls, acids, alcohols, esters, lactones, and various other hydrocarbon compounds.

The compounds found in liquid smoke can affect the taste, $\mathrm{pH}$, and storability of the product. The carbonyl compound will react with proteins to produce a product color. Phenols which are the main source of flavor will show bacterial and antioxidant activity. The smoke composition is influenced by various factors, including wood type, wood moisture content, and combustion temperature used. The type of raw material (wood or other plants) used in the pyrolysis process determines the composition of smoke. For example, hardwood generally has a different composition from softwood.

\subsection{Liquid Smoke Classification}

Liquid smoke produced from the pyrolysis process needs to be carried out a purification process in which this process determines the type of liquid smoke produced. The types of liquid smoke are divided into several grades, namely grades 1, 2, and 3. Grade 1 liquid smoke is liquid smoke resulting from distillation and filtering with zeolites which are then continued with fractionation distillation, and then proceed with filtering with activated charcoal. This liquid smoke has a pale yellow color and is used for fast food ingredients such as wet noodles, meatballs, tofu, and various other foods (Yulstiani, 2008)[20].

\subsection{Liquid Smoke Purification}

When steam is produced from a mixture, it contains more volatile components so that the process of separating the components from the mixture can occur (Astuti, 2000)[24]. The compounds contained in liquid smoke have different boiling points so that liquid smoke can be fractionated to obtain the desired functional properties. One method of fractionation that can be done is by liquid smoke redistillation. The liquid smoke distillation process can also eliminate unwanted compounds, namely tar compounds and aromatic polycyclic hydrocarbons (PAH) (Atmaja, 2009)[25].

\subsection{Phenol}

Phenol or carbolic acid or benzenol are colorless crystalline substances that have a characteristic odor. Its chemical formula is $\mathrm{C} 6 \mathrm{H} 5 \mathrm{OH}$ and its structure has a hydroxyl group $(-\mathrm{OH})$ that binds to the phenyl ring. The word phenol also refers to several substances that have an aromatic ring that binds to the hydroxyl group. Having an aromatic ring with one or more hydroxyl groups, often joined with glucosides and usually found in the cell cavity.

Phenol or carbolic acid or benzenol are colorless crystalline substances that have a characteristic odor. Its chemical formula is $\mathrm{C} 6 \mathrm{H} 5 \mathrm{OH}$ and its structure has a hydroxyl group $(-\mathrm{OH})$ that binds to the phenyl ring. The word phenol also refers to several substances that have 
an aromatic ring that binds to the hydroxyl group. Have an aromatic ring with one or more hydroxyl groups, often joined with glucosides, and are usually found in cell cavities.

\subsection{Liquid Smoke Application}

One of the advantages of liquid smoke is that it can be applied to foods that are usually not smoky. Liquid smoke has been widely applied to the processing, including processed meat, fish, and cheese. Liquid smoke is also used to add a sense of smoke to sauces, soups, canned vegetables, and spice mixes. The new application of liquid smoke is to add flavor to foods that are reduced in fat. According to Varnam and Sutherland (1995)[29], liquid smoke is easier to use, more economical and can be applied at the desired temperature, it is also possible to fractionate liquid smoke to obtain the desired organoleptic properties. Liquid smoke can be applied to products in various ways.

Liquid smoke mixing can be done by adding directly to products such as sausages, salami, topical cheese, roasted meat emulsions, and others. The amount of liquid smoke that is added to the product is between 0.1$1 \%$ of the weight of the product ingredient to be preserved with liquid smoke.

\section{METHODOLOGY}

\subsection{Tools and Materials}

The tools used in this study are balance sheets, filter paper, Erlenmeyer, dropper pipettes, measuring cups, Petri dishes, test tubes, pyrolysis devices, and distillation devices. The materials used in this study are mackerel fish, rubber seeds, rubber seed shells, and distilled water.

\section{2. $\quad$ Procedure}

\subsubsection{Pyrolysis Reactor Preparation}

The main components of pyrolysis reactors consist of furnaces and condensers. The furnace functions as fuel combustion and charcoal combustion (rubber seeds and rubber shells), which then produces smoke through the pyrolysis process, while the condenser is a cooling chamber to convert vapor-based smoke into a liquid with the help of cooling media.

\subsection{Pyrolysis Tool Design}

The process of making liquid smoke is carried out using a pyrolysis tool consisting of 2 components, namely furnace and condenser. The furnace is used as a kiln, so it produces smoke from raw materials. While the condenser is used to condense the smoke produced and convert it into a liquid phase. Materials used in the manufacture of pyrolysis devices are plates and pipes made of stainless steel and copper.

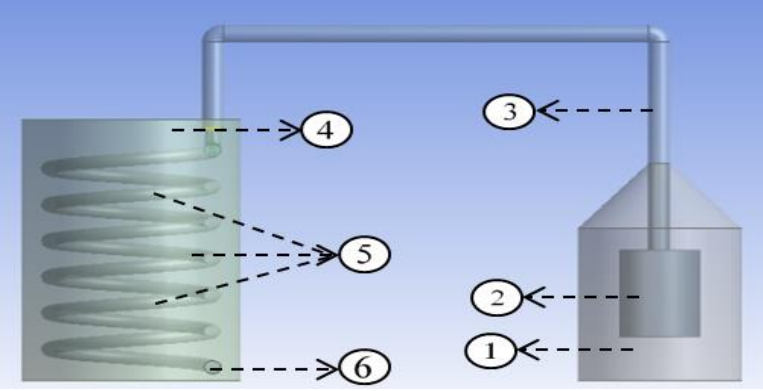

Figure 1 Pyrolysis Tool Series

Information :

1) Furnace (Combustion Room)

2) Raw material's room

3) Smoke Exit Pipe

4) Condenser

5) Coil (spiral column)

6) Liquid Smoke Exit Pipe

This pyrolysis tool is made with a batch system, which aims at a simpler process. The raw material needed for one batch is $1 \mathrm{~kg}$ of rubber seeds or rubber seed shells with a time of 2 hours to produce liquid smoke with different amounts according to the raw material.

\subsubsection{Description of the Toolkit}

The furnace is divided into 2 parts, namely the combustion chamber and material chamber The combustion chamber functions as a fuel, the fuel used is dry wood. Furnace made of stainless steel with the following dimensions:

- $\quad$ Tube diameter: $30 \mathrm{~cm}$

- $\quad$ Tube height: $50 \mathrm{~cm}$

- $\quad$ High connecting pipe: $30 \mathrm{~cm}$

- $\quad$ Connecting pipe diameter: $4 \mathrm{~cm}$

The combustion chamber is made using a zinc plate which is connected directly to the smoke outlet pipe, the combustion chamber has the following dimensions:

- $\quad$ Tube diameter: $15 \mathrm{~cm}$

- $\quad$ High tube: $20 \mathrm{~cm}$

The condenser functions as a cooling chamber to convert the saturated vapor phase into a liquid phase. The cooling media used is water Condenser tubes are made of stainless steel with the following dimensions:

- $\quad$ Tube diameter: $40 \mathrm{~cm}$

- Tube height: $60 \mathrm{~cm}$

- Connecting pipe height: $20 \mathrm{~cm}$

- $\quad$ Connecting pipe diameter: $4 \mathrm{~cm}$ 
The inside of the condenser has a spiral pipe (coil) that functions as a place for the flow of smoke from the vapor phase to the liquid phase. The coil is made of copper with a diameter of $3 \mathrm{~cm}$ and a length of 6 meters.

Several things must be considered to produce a good pyrolysis process. For example, the position of the appropriate charcoal room, so that the smoke can go directly to the smoke exit pipe. The heating in the combustion chamber must be stable. The temperature of the cooling water must be maintained so that the condensation process can be maximized so that the product produced is smoke that has changed phase to become liquid. Finally, the position of the coil must decrease, it is intended that viscous liquid smoke can still flow.

\subsubsection{Raw Material Preparation}

The raw material preparation is rubber seeds. The raw material preparation is $2 \mathrm{~kg}$ for each sample, so it needs to be prepared for about $6 \mathrm{~kg}$ of raw material. Rubber seeds soaked in water for 24 hours which serves to eliminate the content of cyanide acid. Then the rubber seeds are crushed and separated between the contents and the shell.

\subsubsection{Liquid Smoke}

Raw materials that are converted into liquid smoke are divided into 3 types, namely rubber seeds, rubber shells, and a mixture of both. Making liquid smoke is done by inserting $1 \mathrm{~kg}$ of raw materials into the furnace which is carried out for 2 hours so that liquid smoke is produced from the pyrolysis process.

\subsubsection{Liquid Smoke Purification}

Purification of liquid smoke serves to take the compounds needed for food preservation (in the study will use mackerel ), which must be separated from tar in the liquid smoke. Thus, liquid smoke that was originally dark in color will turn to a more transparent color and can be a food preservative.

\subsubsection{Liquid Smoke Analysis}

The GCSM test functions to determine the component compounds present in liquid smoke qualitatively. The GCMS test is conducted at the Integrated Testing Laboratory of the Faculty of Mathematics and Natural Sciences.

ALT test was conducted to determine the ability of liquid smoke as a food preservative. ALT test was carried out on mackerel, namely by comparing the number of bacteria in the sample without soaking liquid smoke and with soaking liquid smoke with various variations of immersion time.

The $\mathrm{pH}$ test is performed on each liquid smoke sample after the distillation process before it is used as a food preservative. The $\mathrm{pH}$ test is carried out using a $\mathrm{pH}$ indicator paper.

\section{RESULT AND DISCUSSION}

\subsection{Raw Materials Preparation}

The raw material used in this study is rubber seeds obtained from rubber plantations in South Sumatra. Rubber seeds obtained from these plantations are sorted beforehand to separate rubber seeds that are feasible and not feasible. The next step is the process of removing cyanide acid ( $\mathrm{HCN})$ content in the rubber seeds. Because this rubber seed will be used as a food product, the cyanide acid removal process is very important to eliminate the toxin content. The cyanide acid removal process is carried out in 3 stages, namely washing, soaking, and boiling stages. Washing is done using clean water 3-5 times, soaking rubber seeds for 24 hours, while boiling rubber seeds is done for 1.5 hours. After washing, soaking, and boiling, it is necessary to do a drying process that affects the process of reducing cyanide acid levels and avoiding mold growth and decay.

The preparation of the next raw material is to reduce the size of the rubber seeds. This study uses 3 variations of raw materials, the first using a shell of rubber seeds, the second uses the contents of the rubber seeds, and when using a combination of shells and the contents of rubber seeds. The raw material preparation is $1 \mathrm{~kg}$ of raw material for each sample variation in each batch of process. The function of this process is to facilitate the combustion process of raw materials to be converted into liquid smoke, the smaller the size of raw materials, the ability of raw materials to burn until they run out the better. Meanwhile, if the size reduction process is not carried out, it is feared that it will cause raw materials to be difficult to burn in the pyrolysis process. There is no specific size for the raw material before it is put into the furnace, the most important thing is that every part of the raw material has broken so it can be more easily converted to smoke.

\subsection{GCMS Analysis}

This study uses rubber seeds (which are separated into rubber seeds and rubber seed shells), due to the cellulose, lignin, and hemicellulose content of the rubber seeds. So that when assessed based on the content of rubber seeds, the rubber seeds can be converted into liquid smoke as in general. The content of rubber seeds is $33.54 \%$ lignin, $48.64 \%$ cellulose, and $17.82 \%$ other compounds.

Gas Chromatography-Mass Spectroscopy (GCMS) analysis is a method of separating organic compounds using two compound analysis methods, gas chromatography (GC) to separate compounds into singles, and mass spectroscopy (MS) to analyze the 
molecular structure of analyses. In this study, GC-MS analysis of rubber seed shell samples was carried out. The results of the GC-MS analysis of liquid smoke from rubber seed shells are as follows:

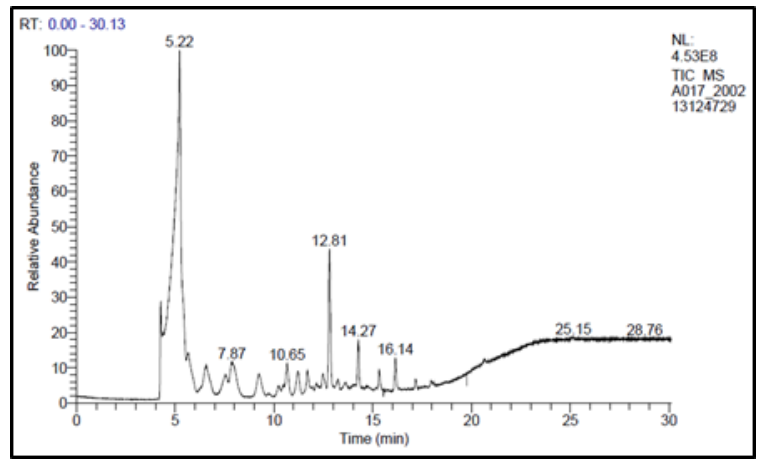

Figure 2 GCMS Analysis Results

GCMS analysis on liquid smoke was carried out with a total retention time of 30.09 minutes with an operating temperature of 300 0C. Based on the table above, it can be seen that the product content of the pyrolysis of rubber seeds into liquid smoke consists of hydrocarbon compounds with fractions $\mathrm{C} 1$ to $\mathrm{C} 19$. GCMS analysis results in this sample contain various kinds of compounds that are dominated by phenol, furan, ketone, and acid compounds. This indicates that the liquid smoke produced can be used for food preservatives because it is dominated by phenol group compounds, which is around $33.15 \%$.

Table 3 Area Results in GC-MS Analysis

\begin{tabular}{clll}
\hline No & $\begin{array}{l}\text { Molecular } \\
\text { Formula }\end{array}$ & \multicolumn{1}{c}{ Component } & Area (\%) \\
\hline 1. & $\mathrm{C}_{9} \mathrm{H}_{11} \mathrm{O}_{3}$ & Phenol, 2-methoxy & 23,45 \\
2. & $\mathrm{C}_{5} \mathrm{H}_{6} \mathrm{O}_{2}$ & 3-Furanmethanol & 12,31 \\
3. & $\mathrm{C}_{8} \mathrm{H}_{10} \mathrm{O}_{2}$ & Creosol & 7,38 \\
4. & $\mathrm{C}_{9} \mathrm{H}_{18} \mathrm{O}_{2}$ & Ethyl 2-heptanoate & 6,9 \\
5. & $\mathrm{C}_{6} \mathrm{H}_{8} \mathrm{O}_{3}$ & 2-Cyclopenten-1- & 4,54 \\
& & one,2-hydroxy-3- & \\
& & methyl & \\
6. & $\mathrm{C}_{8} \mathrm{H}_{10} \mathrm{O}_{3}$ & Phenol,2,6-dimethoxy & 4,53 \\
7. & $\mathrm{C}_{6} \mathrm{H}_{5} \mathrm{OH}$ & Phenol & 4,82 \\
8. & $\mathrm{C}_{4} \mathrm{H}_{8} \mathrm{O}_{2}$ & 1-Hydroxy-2-Butanone & 3,96 \\
9. & $\mathrm{C}_{6} \mathrm{H}_{10} \mathrm{O}_{2}$ & 1H-Imidazole, 2,4,5,- & 3,12 \\
& & trimethyl & \\
10. & $\mathrm{CH}_{3} \mathrm{COH}$ & Acetic Acid & 2,78 \\
\hline
\end{tabular}

Acid compounds are formed due to long time and high temperatures, especially acetic acid. While phenol compounds derived from lignin in the rubber seed samples that degraded at high temperatures. The content of phenol compounds in liquid smoke functions as an antioxidant that can extend the shelf life of a food ingredient and can inhibit and prevent the growth of a microbe in a food ingredient.

\subsection{Analysis of $p H$ Values}

The $\mathrm{pH}$ value is one of the indicators or parameters used to determine the freshness level of fish. In fish $\mathrm{pH}$ usually is between $6.4-6.6$ or close to neutral. If the $\mathrm{pH}$ exceeds 7 , the fish will be easily damaged, due to low glycogen reserves in fish meat (Buckle, 1987)[30]. So, if the liquid smoke produced has an acidic $\mathrm{pH}$, it will maintain the $\mathrm{pH}$ of the mackerel in acidic conditions. If the liquid smoke produced has an alkaline $\mathrm{pH}$, then it will make the $\mathrm{pH}$ of mackerel fish more easily to become alkaline and experience decay and physical damage.

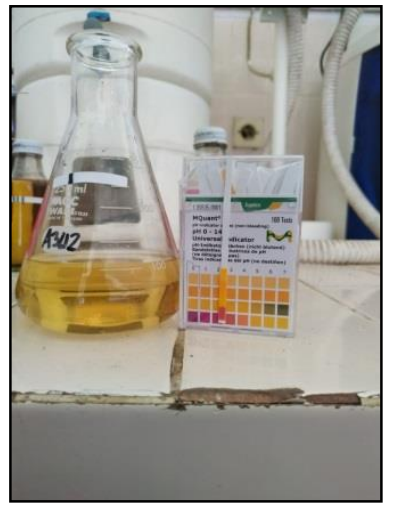

Figure 3 PH testing

Based on the $\mathrm{pH}$ test conducted on all liquid smoke samples, the following $\mathrm{pH}$ values are obtained:

Table 4 Analysis of $\mathrm{pH}$ of Liquid Smoke samples

\begin{tabular}{ll}
\hline Raw Material & $\mathrm{pH}$ \\
\hline Rubber Shell & 3 \\
Rubber Shells and Seeds & 4,5 \\
Rubber Seed & 8 \\
\hline
\end{tabular}

Table 4 shows the results that liquid smoke with rubber shell raw material and the combination of shell and rubber seeds have an acidic $\mathrm{pH}$, whereas for liquid smoke with rubber seed raw materials have a basic $\mathrm{pH}$. So that when viewed from the $\mathrm{pH}$, rubber seeds have a lower quality. 


\subsection{Analysis of Total Plate Numbers (ALT)}

As a preservative, liquid smoke has many advantages, including phenol, carbonyl, and acids. The phenol content in liquid smoke acts as an antioxidant to prevent damage caused by the oxidation process. The acid in liquid smoke will affect the taste, $\mathrm{pH}$, and shelf life of products preserved with liquid smoke. While carbonyl in liquid smoke that reacts with the protein in the product affects the color of the preserved product so that it will produce a uniform color and taste in the preserved product.

Purification of liquid smoke aims to minimize the amount of tar in liquid smoke. Purification can be done by the distillation process. Distillation is the process of separating a solution based on differences in boiling points. Using the basis that some components can evaporate faster than other components. In the process of distillation of liquid smoke, which is used as a preservative is the distillate which is part of raw liquid smoke that has evaporation. According to Darmaji (2002)[32], the distillation temperature of liquid smoke can be carried out from a temperature of $100 \mathrm{oC}$ to $150 \mathrm{oC}$. So in this study, the distillation temperature used is $150 \mathrm{oC}$.

\subsubsection{Results of Analysis of Total Plate Figures}

This study uses mackerel (Euthynus affinis) as ingredients to be tested as a preservative product using liquid smoke. This study had 45 samples, consisting of 3 variations of the time immersed mackerel in liquid smoke (30 minutes, 60 minutes, and 90 minutes) and 5 variations in concentration $(3 \%, 6 \%, 9 \%, 12 \%$, and $15 \%$ ) so that the total sample is 45 samples.

Based on table 4, there is a sample used as a comparison sample. The treatment of this sample is sufficient to be allowed to stand for the specified time (30 minutes, 60 minutes, and 90 minutes), and then an analysis of the total plate count is carried out.

Table 5 Number of Colonies in Samples Without Soaking Liquid Smoke

\begin{tabular}{|c|c|c|}
\hline Sample Code & Time (s) & $\sum_{\text {ALT }}$ (CFU/g) \\
\hline A0 & 30 & $2,97 \times 10^{4}$ \\
\hline B0 & 60 & $5,24 \times 10^{4}$ \\
\hline C0 & 90 & $2,17 \times 10^{5}$ \\
\hline
\end{tabular}

The number of colonies gained is greater with increasing time. When the sample was allowed to stand for 30 minutes the number of colonies was $2.97 \times 104$ CFU / gram, 60 minutes had the number of colonies
$5.24 \times 104 \mathrm{CFU} /$ gram, and 90 minutes had the number of colonies $2.17 \times 105$.

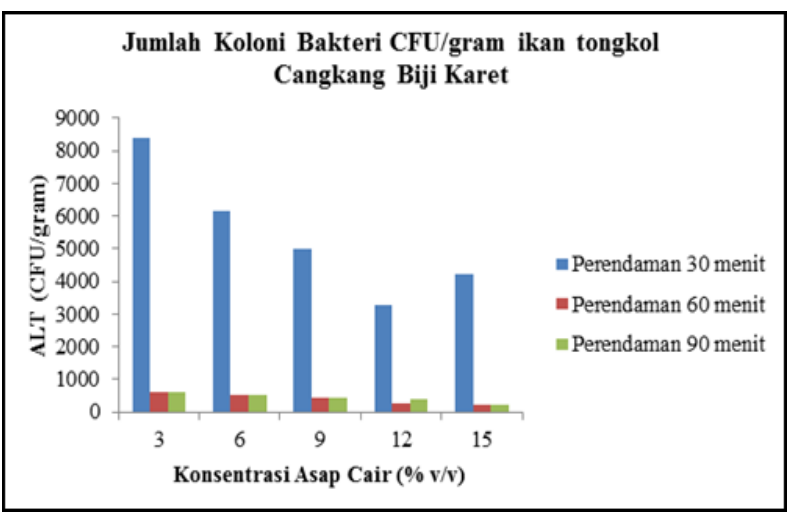

Figure 4 The number of bacterial colonies in rubber seedling shell raw material with variations in immersion time and concentration

The first sample tested was mackerel fish soaked in liquid smoke originating from a rubber seed shell. Samples soaked for 30 minutes showed a decrease in each concentration, the number of colonies in the 30minute control variable was $2.97 \times 104 \mathrm{CFU} /$ gram to $3.28 \times 103-8.4 \times 103 \mathrm{CFU} /$ gram. The best results for rubber seed shell samples with a soaking time of 30 minutes is at a concentration of $12 \%$.

The second sample tested was fish soaked for 60 minutes showing a decrease in each concentration, the number of colonies in the 60-minute control variable was 5.24 x $104 \mathrm{CFU} /$ gram to 2.115 x 102 - 5.91 x 102 CFU / gram. The best results for rubber seed shell samples with 60 minutes soaking time is at a concentration of $15 \%$.

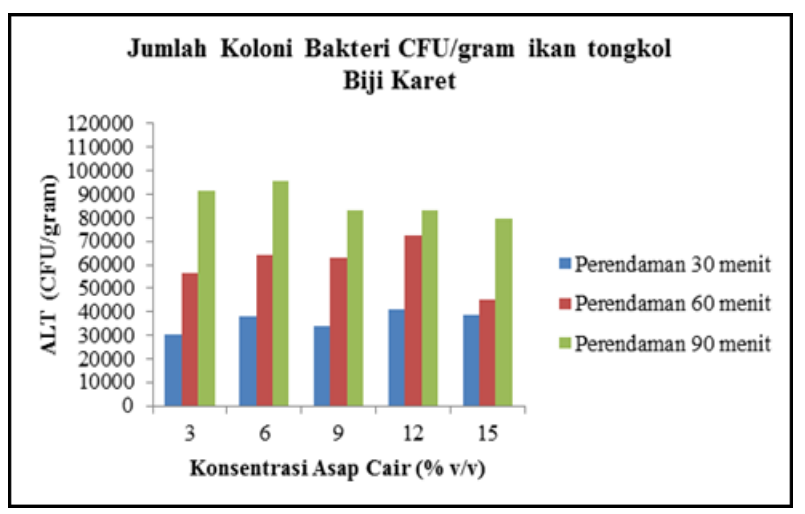

Figure 5 The number of bacterial colonies in rubber seed raw material with variations in immersion time and concentration

The third sample tested was mackerel fish soaked for 90 minutes showing a decrease in each concentration, the number of colonies in the 90-minute control variable was $2.17 \times 105 \mathrm{CFU} /$ gram to $2.12 \mathrm{x}$ 102 - 6.1 x $102 \mathrm{CFU} /$ gram. The best results for rubber seed shell samples with 90 minutes soaking time were at a concentration of $15 \%$. 


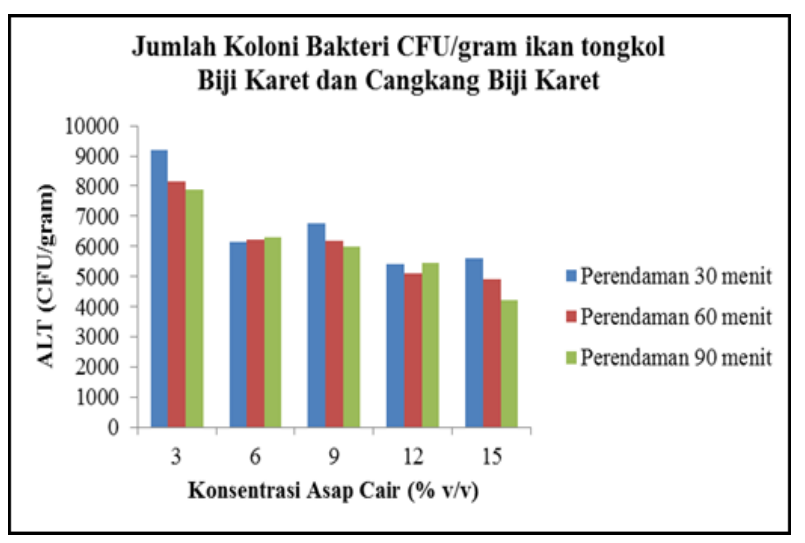

Figure 6 The number of bacterial colonies in the raw material of rubber seeds and rubber seed shells with variations in immersion time and concentration

\subsubsection{Application of liquid smoke as a preservative}

The utilization of liquid smoke is applied as a preservative for mackerel, which is analyzed based on the number of bacterial colonies. Fish has a threshold (Indonesian National Standard) SNI for quality requirements and food safety of fresh fish if the number of bacterial colonies does not exceed 5 x $105 \mathrm{CFU} /$ gram of fish. Based on research that has been done, all samples meet Indonesian national standards. However, if sorted based on the efficiency of liquid smoke to become a preservative for mackerel, then the best liquid smoke is from the raw material of the rubber seedling shell, followed by a raw material consisting of a rubber seedling shell and a rubber seed, then liquid smoke with a rubber seed raw material. This is based on the content of the rubber seed shell which contains a lot of phenols, and liquid smoke from the rubber seed shell has a more acidic $\mathrm{pH}$ than the others.

The best concentration of almost all samples is $15 \%$, so it can be concluded that the higher the concentration of liquid smoke, the better. Especially in rubber seed shell raw material. However, some samples have good results at $9 \%$. So it can be concluded that at a concentration of $9 \%$ it has been able to become a fish preservative, due to a concentration of $12 \%$ and $15 \%$ only a slight decrease in the number of bacteria.

The best soaking time for mackerel in liquid smoke is 90 minutes. However, soaking 60 minutes is good enough to reduce the number of colonies. Whereas the 30-minute immersion is not good enough, because the number of reduced colonies is still relatively small. So that if concluded, then the 60 minute soaking time is enough to reduce the number of colonies in fish, but at 90 minutes has better results. Therefore, the best result is a 90 minute soaking time, a concentration of $15 \%$, with the raw material of a rubber seedling shell.
Some things that must be evaluated from this research are, the incubation time which is only 24 hours can be extended to 48 hours, so we get control variables that have colony values exceeding SNI so that the effect of liquid smoke on the number of colonies will be more apparent.

Research that has been done refers to various previous studies. The first research that became a reference was from a study entitled "Preservation of Bloated Fish Using Liquid Smoke from Rubber Wood Branches (Hevea Brasiliense)" (Ali, Farida. and Joni Iskandar, 2020)[33][34]. In this study using a pyrolysis tool in PT. Sumbawa Banyuasin Plantation, while in this study using a simpler pyrolysis design.

The study varied the incubation time, while our study varied the immersion time of the fish before being tested using a Total Plate Number (ALT) analysis to determine the number of microbes in each gram of fish that had been soaked by liquid smoke. The study conducted variations in the concentration of liquid smoke that is $5 \%, 10 \%$, and $15 \%$, while research conducted using liquid smoke concentrations of $3 \%$, $6 \%, 9 \%, 12 \%$, and $15 \%$ to obtain optimal results due to the number of variables more.

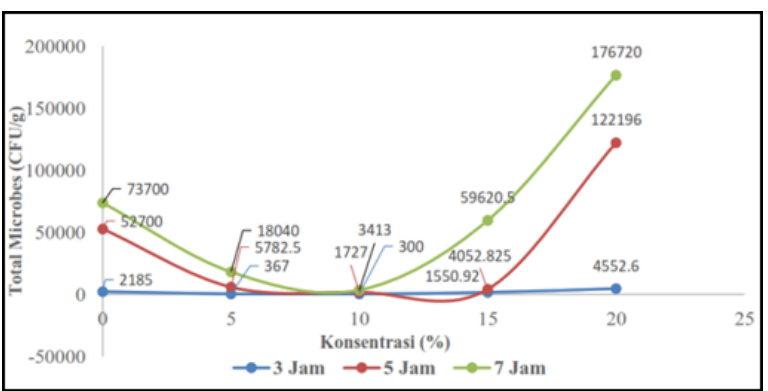

Figure 7 Effect of Concentration on Total Microbes in Bloated Fish

The best results obtained in the study were at a concentration of $10 \%$ with an incubation time of 3 hours with a total plate count of $3 \times 102 \mathrm{CFU} /$ gram. So it can be concluded that liquid smoke from rubber-wood material can reduce the number of bacteria found in mackerel and can be used as a preservative.

Previous research that was also a reference for this study was from a study entitled "Preservation of Tilapia Using Liquid Smoke from Rubber Wood Branches" (Ali, Farida, and Roval Al Fiqri, 2019)[35]. The best results were shown at incubation time for 3 hours. Liquid smoke with a concentration of $6 \%$ has experienced an increase in bacterial population growth from $0 \mathrm{CFU} / \mathrm{g}$ to $3 \mathrm{x} 102$. At a liquid smoke concentration of $8 \%$, an increase in the total plate number to $7.5 \times 102 \mathrm{CFU} / \mathrm{g}$, and the concentration of liquid smoke $10 \%$ causes an increase in the total plate number to $1.83 \times 103 \mathrm{CFU} / \mathrm{g}$. Based on the results of the total plate count test for 7 hours, the ability of liquid smoke to inhibit bacterial growth is best at a 
concentration of $6 \%$ with the total plate count is $3 \times 102$ $\mathrm{CFU} / \mathrm{g}$.

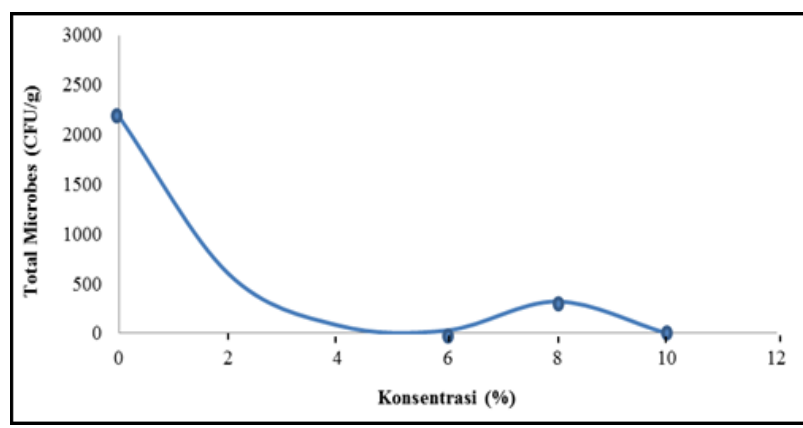

Figure 8 Effect of Concentration on Total Microbes in Parrotfish

The study varied in the incubation time, which when observed from the research data had unstable results. This is concluded from the number of microbes that tend to increase at certain concentrations in a longer soaking time. However, it can be concluded that liquid smoke from rubberwood can reduce the number of microbes in parrotfish.

Another research that is being referred to is from a study entitled "Liquid Smoke Application from Pyrolysis Process of Shells and Rubber Seeds as Fish Preservatives" (Ali, Farida. et al., 2020)[35] This research uses various variables (immersion duration and concentration of liquid smoke) the same and uses catfish as a type of test material from liquid smoke from rubber seeds. Variable duration of fish immersion before analysis of the total plate number was carried out to obtain the optimum immersion time in using liquid smoke as a preservative, compared to the variation of the incubation time because the number of microbes would continue to increase along with the incubation time increase in the total plate rate analysis process.

Table 6 ALT analysis of mackarel and patin (CFU/gram)

\begin{tabular}{|c|c|c|c|c|c|c|c|}
\hline \multirow{3}{*}{$\begin{array}{c}\text { Bahan } \\
\text { Baku }\end{array}$} & \multirow{3}{*}{$\begin{array}{l}\text { Konsentrasi } \\
\text { Asap Cair }\end{array}$} & \multicolumn{6}{|c|}{ Variasi Waktu Perendaman } \\
\hline & & \multicolumn{2}{|c|}{30 Menit } & \multicolumn{2}{|c|}{60 Menit } & \multicolumn{2}{|c|}{90 Menit } \\
\hline & & Tongkol & Patin & Tongkol & Patin & \begin{tabular}{|l|} 
Tongkol \\
\end{tabular} & Patin \\
\hline \multirow{6}{*}{$\begin{array}{l}\text { Cangkang } \\
\text { Biji Karet }\end{array}$} & $0 \%$ & 29.700 & 11.150 & 52.400 & 37.800 & 217.000 & 520.000 \\
\hline & $3 \%$ & 8.400 & 7.420 & 591 & 715 & 610 & 724 \\
\hline & $6 \%$ & 6.140 & 6.510 & 530 & 600 & 528 & 680 \\
\hline & $9 \%$ & 5.000 & 5.540 & 431 & 570 & 413 & 511 \\
\hline & $12 \%$ & 3.280 & 5.550 & 262 & 517 & 383 & 518 \\
\hline & $15 \%$ & 4.216 & 5.520 & 212 & 526 & 212 & 512 \\
\hline \multirow{6}{*}{$\begin{array}{c}\text { Cangkang } \\
\text { Biji Karet } \\
\text { + Biji } \\
\text { Karet }\end{array}$} & $0 \%$ & 29.700 & 11.150 & 52.400 & 37.800 & 217.000 & 520.000 \\
\hline & $3 \%$ & 9.200 & 11.100 & 8.140 & 7.213 & 7.890 & 6.290 \\
\hline & $6 \%$ & 6.130 & 89.520 & 6.210 & 6.200 & 6.320 & 6.300 \\
\hline & $9 \%$ & 6.756 & 7.856 & 6.200 & 6.317 & 6.000 & 5.000 \\
\hline & $12 \%$ & 5.410 & 5.200 & 5.100 & 5.100 & 5.440 & 5.125 \\
\hline & $15 \%$ & 5.620 & 5.320 & 4.920 & 5.420 & 4.210 & 5.276 \\
\hline \multirow{6}{*}{$\begin{array}{c}\text { Biji } \\
\text { Karet }\end{array}$} & $0 \%$ & 29.700 & 11.150 & 52.400 & 37.800 & 217.000 & 520.000 \\
\hline & $3 \%$ & 30.500 & 21.800 & 56.400 & 32.600 & 91.200 & 24.100 \\
\hline & $6 \%$ & 38.100 & 31.620 & 63.900 & 35.900 & 95.400 & 25.200 \\
\hline & $9 \%$ & 34.000 & 36.400 & 63.000 & 41.820 & 83.000 & 31.700 \\
\hline & $12 \%$ & 41.100 & 28.200 & 72.200 & 51.300 & 83.200 & 24.100 \\
\hline & $15 \%$ & 38.900 & 30.000 & 45.200 & 31.280 & 79.700 & 38.000 \\
\hline
\end{tabular}

Based on the table, some discussions were obtained on the comparison of mackerel and catfish in liquid smoke applications with the same concentration and immersion time. The liquid smoke in catfish has optimum conditions on the raw material of rubber seed shells with a concentration of $9 \%$ and a soaking time of 90 minutes. While the application of liquid smoke on mackerel has optimum conditions on the raw material of rubber seed shells with a concentration of $15 \%$ and a soaking time of 60 minutes.

The results of the analysis of total plate numbers in the two types of fish have a slightly different graphic pattern, but it can be concluded that liquid smoke has shown good results at a concentration of $9 \%$, and then proceed at a concentration of $12 \%$ and $15 \%$, especially in raw material for seed shells rubber because of its lignin content. The immersion duration variable indicates that the liquid smoke is optimum at 60 minutes, but it will be better if it is soaked in 90 minutes.

Based on several studies that have been carried out and then compared, the results are obtained that liquid smoke from rubber wood raw material and rubber seed shells (as well as various other raw materials that contain lignin), can be converted to liquid smoke which will then be used as a preservative for fish (parrotfish, mackerel, catfish, and mackerel).

\section{CLOSING REMARK}

\subsection{Conclusion}

The conclusions of this study are:

1) A simple pyrolysis tool is designed using a batch system of stainless steel for furnaces and condensers.

2) The best raw materials are raw materials with rubber seed shells because they have higher lignin content.

3) GCMS analysis results on shell smoke and rubber seeds containing various compounds such as phenols, furans, ketones, acids, etc.

4) The total plate number decreases with each additional concentration, ie at a concentration of $9 \%$ it has been able to reduce the number of bacterial colonies, and for concentrations of $12 \%$ and $15 \%$ also decreased but not too significant.

5) Liquid smoke products from rubber seed shells have the most optimum ability to inhibit bacterial activity with a total plate value of $2.12 \times 102 \mathrm{CFU} /$ gram of mackerel.

6) The $\mathrm{pH}$ value of the liquid smoke product is the liquid smoke with rubber seed shell (ie acidic $\mathrm{pH}$ ), while the rubber seed raw material has a basic $\mathrm{pH}$.. 


\subsection{Suggestion}

1) We recommend adding a variable in the form of temperature variations during the pyrolysis process.

2) The incubation time should be extended to 48 hours so that the results of the reduced number of colonies can be more visible.

3) We recommend that the length of the coil inside the condenser must be considered, so that smoke that has changed phase into liquid is not clogged because liquid smoke has a high viscosity.

4) Further research should be carried out on products that have been soaked with liquid smoke so that a food eligibility test can be carried out.

\section{REFERENCES}

[1] [1] (Kementrian Pertanian, 2018).

[2] Fadillah, H. dan Alfiarty, A. 2015. The influence of Pyrolysis Temperature and Time to the Yield and Quality of Rubber Fruit Shell Liquid Smoke. Prosiding Seminar Nasional Teknik Kimia.

[3] Setyawardhani, D. A., Distantina, S., Henfiana, H., dan Dewi, A. S. 2010. Pembuatan Biodiesel dari Asam Lemak Jenuh Minyak Biji Karet. Prosiding Seminar Nasional Rekayasa Kimia dan Proses. Semarang: Univesitas Diponegoro.

[4] Setyawardhani, D. A., Distantina, S., Henfiana, H., dan Dewi, A. S. 2010. Pembuatan Biodiesel dari Asam Lemak Jenuh Minyak Biji Karet. Prosiding Seminar Nasional Rekayasa Kimia dan Proses. Semarang: Univesitas Diponegoro.

[5] Eka, H. D., Aris, T. Y., dan Nadiah, W. A. 2010. Potential Use of Malaysian Rubber (Hevea brasiliensis) Seed as Food, Feed, and Biofuel. Int Food Res Journal. Vol.17 (1): 527-534.

[6] Eka, H. D., Aris, T. Y., dan Nadiah, W. A. 2010. Potential Use of Malaysian Rubber (Hevea brasiliensis) Seed as Food, Feed, and Biofuel. Int Food Res Journal. Vol.17 (1): 527-534.

[7] Safitri, E. S. 2003. Komposisi Kimia Cangkang Buah Karet. Jurnal Penelitian Karbon Aktif. (Skripsi). Indralaya: Universitas Sriwjaya.

[8] Atmaja, A. 2009. Aplikasi Asap Cair Redestilasi pada Karakterisasi Kamaboko Ikan Tongkol (Euthynus affinis) Ditinjau dari Tingkat Keawetan

[9] Girrard. J.P. 1992. The Technology of Meat and Meat Product Smoking. Ellis Harwood.
[10] Atmaja, A. 2009. Aplikasi Asap Cair Redestilasi pada Karakterisasi Kamaboko Ikan Tongkol (Euthynus affinis) Ditinjau dari Tingkat Keaweta

[11] Purwaningtyas, A. 2010. Kajian Optimasi Proses Pirolisismackarel Jagung untuk Produksi Asap Cair. (skripsi). Bogor: Institut Pertanian Bogor

[12] Girrard. J.P. 1992. The Technology of Meat and Meat Product Smoking. Ellis Harwood.

[13] Maga, J.A. 1987. Smoke in Food Processing. Boca Raton: CRC Press.

[14] Sutin. 2008. Pembuatan Asap Cair dari Tempurung Kelapa dan Sabut Kelapa secara Pirolisi serta Fraksinasinya dengan Ekstraksi. Bogor: IPB.

[15] Sutin. 2008. Pembuatan Asap Cair dari Tempurung Kelapa dan Sabut Kelapa secara Pirolisi serta Fraksinasinya dengan Ekstraksi. Bogor: IPB.

[16] Atmaja, A. 2009. Aplikasi Asap Cair Redestilasi pada Karakterisasi Kamaboko Ikan Tongkol (Euthynus affinis) Ditinjau dari Tingkat Keawet

[17] Yulstiani, R. 2008. Monograf Asap Cair sebagai Bahan Pengawet Alami pada Produk Daging dan Ikan. Surabaya: UPN Veteran Jawa Timur

[18] Luditama, C. 2006. Isolasi dan Pemurnian Asap Cair Berbahan Dasar Tempurung dan Sabut Kelapa secara Pirolisis dan Destilasi. (skripsi). Bogor: Institut Pertanian Bogor.

[19] Yulstiani, R. 2008. Monograf Asap Cair sebagai Bahan Pengawet Alami pada Produk Daging dan Ikan. Surabaya: UPN Veteran Jawa Timur

[20] Yulstiani, R. 2008. Monograf Asap Cair sebagai Bahan Pengawet Alami pada Produk Daging dan Ikan. Surabaya: UPN Veteran Jawa Timur

[21] Astuti. 2000. Pembuatan Asap Cair dari Tempurung Kelapa. Laporan Penelitian. Jakarta

Yulstiani, R. 2008. Monograf Asap Cair sebagai Bahan Pengawet Alami pada Produk Daging dan Ikan. Surabaya: UPN Veteran Jawa Timur

[22] Astuti. 2000. Pembuatan Asap Cair dari Tempurung Kelapa. Laporan Penelitian. Jakarta

Yulstiani, R. 2008. Monograf Asap Cair sebagai Bahan Pengawet Alami pada Produk Daging dan Ikan. Surabaya: UPN Veteran Jawa Timur

[23] Astuti. 2000. Pembuatan Asap Cair dari Tempurung Kelapa. Laporan Penelitian. Jakarta 
Yulstiani, R. 2008. Monograf Asap Cair sebagai Bahan Pengawet Alami pada Produk Daging dan Ikan. Surabaya: UPN Veteran Jawa Timur

[24] Atmaja, A. 2009. Aplikasi Asap Cair Redestilasi pada Karakterisasi Kamaboko Ikan Tongkol (Euthynus affinis) Ditinjau dari Tingkat Keawetan

[25] Darmadji, P. dan M. Izomoto. 1995. Antibacterial effects of spices on fermented meat. The Scientific Reports of The Faculty of Agriculture Okayama University. Vol. 83 (1): 9-15.

[26] Karseno, dkk. 2002. Daya Hambat Asap Cair Kayu Karet terhadap Bakteri Pengkontaminan Lateks dan Ribbed Smoke Sheet. Agritech. Vol.2 (1): 10-15.

[27] Ahmad, SS, Mubarik, N.R, Nursyamsi., R, and Septiaji, P., Characterization of Redistilled Liquit

[28] Vranama, H.A. dan Sutherland J.P. (1994). Beverages (Technology, Chemistry, and Microbiology). London: Chapman and Hall.

[29] Vranama, H.A. dan Sutherland J.P. (1994). Beverages (Technology, Chemistry, and Microbiology). London: Chapman and Hall.
[30] Buckle, K.A, 1987, Ilmu Pangan, Jakarta, UI Press.

[31] Darmadji, P. dan M. Izomoto. 1995. Antibacterial effects of spices on fermented meat. The Scientific Reports of The Faculty of Agriculture Okayama University. Vol. 83 (1): 9-15.

[32] Ali, Farida., Joni Iskandar. 2020. Pengawetan Ikan Kembung Menggunakan Asap Cair dari Ranting Kayu Karet. Jurnal Jurusan Teknik Kimia Fakultas Teknik Universitas Sriwijaya.

[33] Ali, Farida., Roval Al Fiqri. 2019. Pengawetan Ikan Nila Menggunakan Asap Cair dari Ranting Kayu Karet. Jurnal Jurusan Teknik Kimia Fakultas Teknik Universitas Sriwijaya.

[34] Ali, Farida., M. Syahrul Sandrea, Ryan Reza Fahlepy. 2020. Aplikasi Asap Cair dari Proses Pirolisa Cangkang dan Biji Karet sebagai Bahan Pengawet Ikan. Jurnal Jurusan Teknik Kimia Fakultas Teknik Universitas Sriwijaya.

[35] Ali, Farida., M. Syahrul Sandrea, Ryan Reza Fahlepy. 2020. Aplikasi Asap Cair dari Proses Pirolisa Cangkang dan Biji Karet sebagai Bahan Pengawet Ikan. Jurnal Jurusan Teknik Kimia Fakultas Teknik Universitas Sriwijaya. 